University of South Carolina

Scholar Commons

6-7-2010

\title{
Tobacco Mosaic Virus Based Thin Film Sensor for Detection of Volatile Organic Compounds
}

\author{
Michael A. Bruckman \\ University of South Carolina - Columbia \\ Jie Liu \\ University of South Carolina - Columbia \\ Goutam Koley \\ University of South Carolina - Columbia \\ Yu Li \\ University of South Carolina - Columbia \\ Brian C. Benicewicz \\ University of South Carolina - Columbia, benice@sc.edu
}

See next page for additional authors

Follow this and additional works at: https://scholarcommons.sc.edu/chem_facpub

Part of the Materials Chemistry Commons

\section{Publication Info \\ Published in Journal of Materials Chemistry, Volume 20, Issue 27, 2010, pages 5715-5719. \\ (c) Journal of Materials Chemistry 2010, Royal Society of Chemistry.}

This Article is brought to you by the Chemistry and Biochemistry, Department of at Scholar Commons. It has been accepted for inclusion in Faculty Publications by an authorized administrator of Scholar Commons. For more information, please contact digres@mailbox.sc.edu. 


\section{Author(s)}

Michael A. Bruckman, Jie Liu, Goutam Koley, Yu Li, Brian C. Benicewicz, Zhongwei Niu, and Qian Wang 


\title{
Tobacco mosaic virus based thin film sensor for detection of volatile organic compounds
}

\author{
Michael A. Bruckman, ${ }^{a}$ Jie Liu, ${ }^{b}$ Goutam Koley, ${ }^{b}$ Yu Li, ${ }^{a}$ Brian Benicewicz, ${ }^{a}$ Zhongwei Niu $* c^{*}$ and Qian Wang ${ }^{* a}$ \\ Received 8th March 2010, Accepted 13th April 2010 \\ First published as an Advance Article on the web 7th June 2010 \\ DOI: $10.1039 / \mathrm{c0jm00634c}$
}

A thin film sensor for the detection of volatile organic compounds (VOC) was fabricated by deposition of oligo-aniline grafted tobacco mosaic virus (TMV) onto a glass substrate. The oligo-aniline motifs were conjugated onto the TMV surface by a traditional diazonium coupling reaction to tyrosine residues followed by $\mathrm{Cu}(\mathrm{I})$ catalyzed alkyne-azide cycloaddition (CuAAC) reaction. The modified TMV was easily fabricated into a thin film by directly drop coating onto a glass substrate. Upon integration of the glass substrate into a prototypical device, the virus-based thin film exhibited good sensitivity and selectivity toward ethanol and methanol vapour.

\section{Introduction}

Biological nanoparticles (BNPs), such as viruses, ferritins, and other protein complexes, represent a class of structurally welldefined nanoscale assemblies. The sizes of BNPs range from $10 \mathrm{~nm}$ to a few hundreds of nanometers with different morphologies. Their three dimensional structures can be characterized at near atomic resolution, which allow genetic manipulation and chemospecific bioconjugation with near atomic precision, providing highly attractive opportunities for the development of nanoscale materials with well-controlled structural features and surface properties. ${ }^{1-16}$ In these respects, BNPs have a great advantage over synthetic nanoparticles such as carbon nanotubes, quantum dots, dendrimers and polymer vesicles. ${ }^{17-19}$ Tobacco mosaic virus (TMV) is among the most well known plant viruses. ${ }^{20,21}$ Thousands of copies of identical coat proteins of TMV are assembled into a $300 \mathrm{~nm}$ helical rod encapsulating its genomic RNA, leaving an interior core with a diameter of $4 \mathrm{~nm}$ and an external diameter of $18 \mathrm{~nm} .{ }^{22} \mathrm{TMV}$ has been employed as a building block or template to produce materials with applications in light harvesting, electronics, energy storage, and cell culturing. ${ }^{3,23-27}$

On the other hand, conducting polymers have found broad applications in electronics, imaging and sensing. ${ }^{28-30}$ In particular, polyaniline (PANI) has received considerable attention due to its environmental stability, ease of synthesis and its well known physical properties. ${ }^{31-33}$ It has been shown that the morphology of PANI is very important to its sensing ability. ${ }^{33-36}$ Previously, we reported the synthesis of PANI-TMV composite nanowires upon coating TMV surface with PANI via noncovalent interactions. ${ }^{24-27}$ Although the synthesis was straightforward, the processing of such nanowires was impeded by the

${ }^{a}$ Department of Chemistry and Biochemistry and Nanocenter, University of South Carolina, Columbia, SC, 29208, USA. E-mail:wang@mail.chem.sc. edu

${ }^{b}$ Department of Electrical Engineering, University of South Carolina, Columbia, SC, 29208, USA

${ }^{c}$ National Engineering Research Center of Plastics, Technical Institute of Physics and Chemistry, Chinese Academy of Sciences, Beijing, 100190, China.E-mail:niu@mail.ipc.ac.cn formation of bundle-like structures, presumably due to the strong interactions between the surface PANI coatings, which limited its applications. Oligoaniline (OANI) is a small molecule precursor of its parent polymer, PANI, which is electroactive, soluble in aqueous solutions, and can be tailored to include any desired functionality. ${ }^{37}$ In particular, OANI has shown similar properties to PANI in directing neural cell growth ${ }^{38}$ and in solution as a TNT sensor. ${ }^{39}$

In our study, we would like to show the potential application of OANI-TMV conjugates as sensor for volatile organic compounds (VOC), in particular, methanol and ethanol. The extended exposure to methanol and ethanol vapours leads to diseases such as eyesight disturbance, nasal mucous membrane, nerve disease and even death, ${ }^{40,41}$ thus the on-line monitoring of these alcohol vapours is very important in many workplaces and laboratories. Recent reports have suggested that BNPs have found applications in chemical and biological sensing. ${ }^{42}$ In this paper, we show that OANI can be directly conjugated onto the surface of TMV through multiple chemical manipulations. Due to the high-density distribution of OANI on the TMV surface and the good processability of OANI modified TMVs, they can be easily fabricated into a thin film and exhibit good sensitivity and high selectivity toward the ethanol and methanol vapours.

\section{Experimental}

\section{Materials}

All reagents were used as received. The virus was prepared as previously described. ${ }^{26}$ Unless otherwise noted, "buffer" refers to $10 \mathrm{mM}$ potassium phosphate buffer, $\mathrm{pH}$ 7.8. Sucrose gradient ultracentrifugation separation of virus samples was performed on a $20 \mathrm{~mL}$ gradient (made of $40 \%(\mathrm{w} / \mathrm{w})$ sucrose solution in buffer, frozen at $-20{ }^{\circ} \mathrm{C}$ and thawed before use) with centrifugation at $90,000 \times g$ for $2 \mathrm{~h}$ with a Beckman SW41 rotor using a Beckman Optima ${ }^{\mathrm{TM}}$ L90 K ultracentrifuge. The concentration of unmodified virus was measured by absorbance at $260 \mathrm{~nm}$; $0.1 \mathrm{mg} / \mathrm{mL}$ of TMV gives a standard absorbance of $0.3 .^{43}$ Modified virus concentrations were measured using a Modified 
Lowry Protein Assay Kit (Pierce). The molecular weight of a single subunit of wild type TMV coat protein is 17,534 Daltons.

Synthesis of alkyne modified TMV (Alkyne-TMV). The diazonium salt was prepared by mixing the following solutions at $4{ }^{\circ} \mathrm{C}$ for $1 \mathrm{~h}$ : $400 \mu \mathrm{L}$ of $0.3 \mathrm{M}$ aqueous $p$-toluenesulfonic acid monohydrate; $25 \mu \mathrm{L}$ of $3.0 \mathrm{M}$ aqueous sodium nitrite; and $75 \mu \mathrm{L}$ of $0.68 \mathrm{M}$ distilled 3-ethynylaniline dissolved in acetonitrile. Subsequently, a stock solution of TMV $(20 \mathrm{mg} / \mathrm{mL}, 1.25 \mathrm{~mL})$ was diluted with borate buffer $(3.3 \mathrm{~mL}, \mathrm{pH} 8.8$, containing $100 \mathrm{mM}$ $\mathrm{NaCl})$. Diazonium salt solution $(450 \mu \mathrm{L})$ was then added to the mixture. The mixture was place in an ice bath for $3 \mathrm{~h}$ while the solution turned a light brown color. Purification of the final product was completed by passing the reaction through a $40 \%$ $(\mathrm{w} / \mathrm{w})$ sucrose cushion at $160,000 \times g$ for $2.5 \mathrm{~h}$. The pellet was redissolved in buffer for future use.

Synthesis of azide modified TMV (Azide-TMV). The bis-1,4azidobenzene $(100 \mathrm{mM}$ in DMSO, $160 \mu \mathrm{L})$ and a solution of Alkyne-TMV (15 mg/mL, $200 \mu \mathrm{L})$ were mixed with Tris buffer $(10 \mathrm{mM}, 580 \mu \mathrm{L}, \mathrm{pH} 8.0)$ and DMSO $(40 \mu \mathrm{L})$. Then solutions of $\mathrm{CuSO}_{4}(100 \mathrm{mM}, 10 \mu \mathrm{L})$ and NaAsc $(200 \mathrm{mM}, 10 \mu \mathrm{L})$ were added and the mixture was incubated at room temperature for $1 \mathrm{~h}$. The reaction mixture was purified via $10-50 \%$ sucrose gradient from which the light scattering region was collected. The modified virus was then pelleted using ultracentrifugation at $160,000 \times g$ for $2.5 \mathrm{~h}$. The pellet was dissolved in buffer.

Synthesis of oligoaniline modified TMV (OANI-TMV). The $\mathrm{OANI}^{37}(100 \mathrm{mM}$ in DMSO, $5.5 \mu \mathrm{L})$ and a solution Azide-TMV $(15 \mathrm{mg} / \mathrm{mL}, 133 \mu \mathrm{L})$ were mixed in Tris buffer $(10 \mathrm{mM}, 547 \mu \mathrm{L}$, $\mathrm{pH}$ 8.0) and DMSO $(294.5 \mu \mathrm{L})$. Then solutions of $\mathrm{CuSO}_{4}$ $(100 \mathrm{mM}, 10 \mu \mathrm{L})$ and $\mathrm{NaAsc}(200 \mathrm{mM}, 10 \mu \mathrm{L})$ were added and the mixture was incubated at room temperature for $1 \mathrm{~h}$. The reaction mixture was purified via dialysis $(100,000$ MWCO dialysis tubing) against nanopure $\mathrm{H}_{2} \mathrm{O}$. The remaining solution concentration was determined using a Modified Lowry Assay (Pierce).

General protocol for preparation of virus solution and sensing plate. Prior to use, the modified virus was dialyzed against nanopure water using a 100,000 MWCO dialysis tubing (Pierce). A virus solution with concentration of $250 \mu \mathrm{g} / \mathrm{mL}$ was prepared. To that solution, $15 \mu \mathrm{L} p$-toluene sulfonic acid ( $0.1 \mathrm{M}$, dopant) was added to reduce the $\mathrm{pH}$ to a value between 3 and 4 . To prepare a sensing plate, $150 \mu \mathrm{L}$ of the viral solution was spread on a glass slide with gold coating at the edge of the surface as two electrodes $(25 \mathrm{~mm} \times 1.5 \mathrm{~mm})$, then allowed to dry in a hood overnight.

General protocol for VOC sensing. After placing the leads on gold electrode parts, the apparatus was assembled as shown in Fig. 3b. There is an inlet and outlet for nitrogen or other gases to flow. The two electrodes are designed to hold the OANI-TMV sensor in place while measuring the current flow through the film. They protrude through the bottom of the container and are hooked up to a Keithley 6487 picoammeter which is used for the current measurements (Labeled A in Fig. 3a). The OANI-TMV sample was evaporated at room temperature onto a custom cut glass slide with dimensions of $1.5 \mathrm{~mm} \times 25 \mathrm{~mm}$. The glass slide was sputter coated with two $40 \mathrm{~nm}$ thick strips of gold (Fig. 3c) prior to sample evaporation. These strips of gold were the intermediate contact between the electrodes and the film. Without the gold strips, the sample was easily scraped off of the glass slide by the electrodes. The edges were sealed with additional parafilm to deter moisture from entering the container. $\mathrm{N}_{2}$ was used to flush the container of unwanted chemicals and is used as a blanking standard. After 30 to $60 \mathrm{~s}$ of $\mathrm{N}_{2}$ gas, the gas inlet and outlet are sealed with caps and the VOC of choice was injected $(50-75 \mu \mathrm{L})$ with a syringe. From that point, the sensor was untouched for $15 \mathrm{~min}$ while collecting data. After this, $\mathrm{N}_{2}$ was once again used to flush out the container of chemicals.

\section{Characterization}

For MALDI-MS analysis, the virus was denatured by adding guanidine hydrochloride $(6 \mu \mathrm{L}, 6 \mathrm{M})$ to the sample $(24 \mu \mathrm{L})$ and mixing for $5 \mathrm{~min}$ at room temperature. Denatured proteins were spotted on MTP 384 massive target plate using Millipore ZipTips $_{\mu \mathrm{C} 18}{ }^{\circledR}$ tips to remove excess salts and assist the binding of protein to the sinapic acid matrix. MALDI-MS analysis was performed using a Bruker Ultra-Flex I TOF/TOF mass spectrometer. For transmission electron microscopy (TEM) analysis, a $20 \mu \mathrm{L}$ sample solution $(0.2 \mathrm{mg} / \mathrm{mL})$ was deposited onto a 300-mesh carbon-coated copper grid for $2 \mathrm{~min}$. The grid was then stained with $20 \mu \mathrm{L}$ of $2 \%$ uranyl acetate for 2 min and was characterized with a Hitachi H-8000 TEM. Tapping mode atomic force microscopy (AFM) images were obtained at ambient conditions using a NanoScope IIIA MultiMode AFM (Veeco). Si tips with a resonance frequency of approximately $300 \mathrm{kHz}$ and a spring constant of about $40 \mathrm{~N} \cdot \mathrm{m}^{-1}$, were used for imaging with a scan rate of $0.5 \mathrm{~Hz}$ were used. UV-vis absorption studies were performed using an Agilent 8453 UV-vis spectrometer.

\section{Results and discussion}

As shown in Scheme 1, TMV was subjected to a three-step bioconjugation protocol to introduce the desired OANI functionality. The initial reaction targeted the phenol side chains of
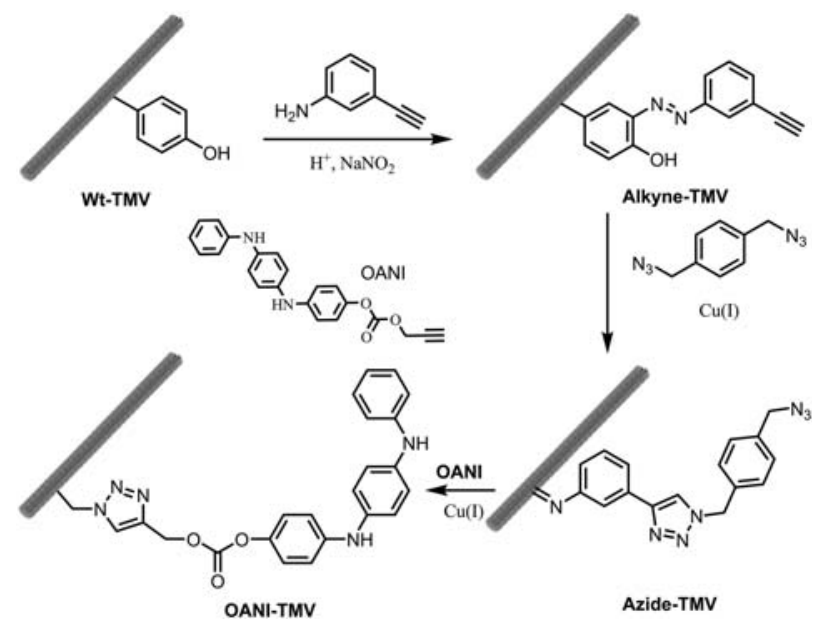

Scheme 1 Synthesis of OANI modified TMV for VOC sensing. 
tyrosine residues of TMV coat proteins to insert a terminal alkyne. ${ }^{1,27,44}$ This was achieved using a diazonium salt generated in situ from 3-ethynylaniline then mixed with TMV to form the corresponding alkyne labeled TMV (Alkyne-TMV). MALDITOF MS analysis indicated that $>95 \%$ of the capsid monomers were converted to the alkyne derivatives as seen in Fig. 1 by the disappearance of a peak at $17534 \mathrm{~m} / \mathrm{z}$ and the introduction of a peak at $17664 \mathrm{~m} / \mathrm{z}$.

The $\mathrm{Cu}(\mathrm{I})$ catalyzed azide-alkyne 1,3-dipolar cycloaddition (CuAAC) between Alkyne-TMV and bis-1,4-azidobenzene in the presence of $\mathrm{Cu}^{\mathrm{I}}$, which was formed in situ by the reduction of $\mathrm{CuSO}_{4}$ with sodium ascorbate, proceeded with $>95 \%$ efficiency to form the azido functionalized TMV (Azide-TMV). These two steps are necessary to introduce the functional azido group onto the surface of TMV. The final step of conjugation was completed following the same CuAAC reaction protocol with OANI and Azide-TMV as starting materials, which afforded OANI-TMV efficiently as shown in Fig. 1.

It is important to know whether TMV remained intact after a three-step bioconjugation. TEM was used to characterize the morphology and aggregation of TMV before and after modifications. As shown in Fig. 2b, after the second step modification (Azide-TMV), TMVs still keep a similar morphology as Wt-TMV (Fig. 2a). Upon conjugation with OANI units, OANITMV still maintains its rod-like structure (Fig. 2c). However, a large amount of aggregation is observed under TEM analysis (Fig. 2c). The aggregation of OANI-TMV is possibly caused by pi-pi interactions and/or the hydrophobic interactions of the OANI motif on the TMV surface between viral particles. To break apart the aggregation of OANI-TMV, DMSO was added into the aqueous solution as the cosolvent to decrease the interactions between OANI units. As visualized by TEM (Fig. 2d), the particles were well-dispersed when the level of DMSO reached $70 \%$, while most of the OANI-TMVs remained intact.

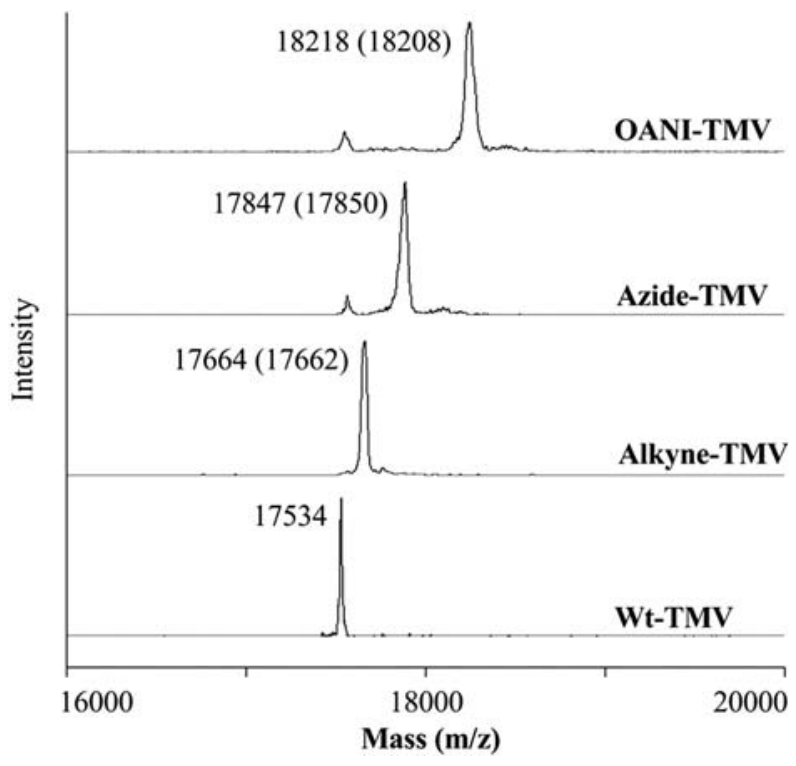

Fig. 1 MALDI-TOF MS of the coat protein of Wt-TMV and modified TMV. The values in parenthesis are the expected $\mathrm{m} / \mathrm{z}$.
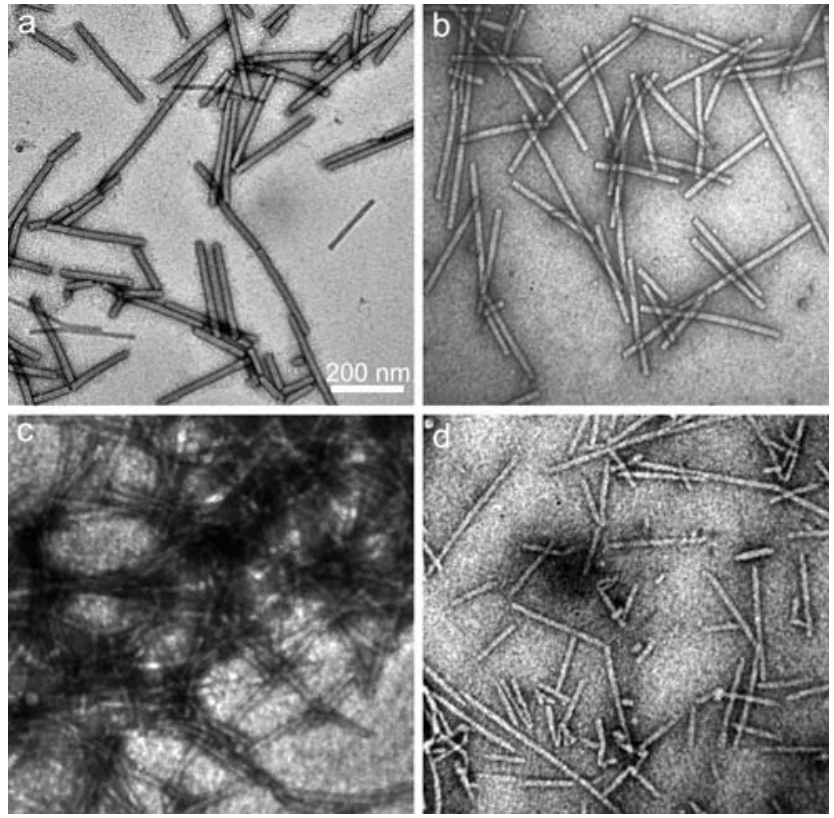

Fig. 2 TEM images of (a) Wt-TMV, (b) Azide-TMV, (c) OANI-TMV, and (d) OANI-TMV in 70\% DMSO. Scale bar is $200 \mathrm{~nm}$ for all images.

Detection of VOCs with OANI-TMV was pursued based on results from previous studies conducted utilizing polyaniline as the sensing material. ${ }^{33,36,45,46} \mathrm{~A}$ simple sensing device with sample container was designed (Fig. 3a) and constructed as shown in Fig. 3b. The sample container has a volume of roughly $12 \mathrm{~mL}$. There is an inlet and outlet for nitrogen or other gases to flow. The two electrodes are designed to hold the OANI-TMV sensor in place while measuring the current flow through the film.

Previous investigations utilizing conducting polymers for sensors indicated that the selection of an appropriate dopant is critical for sensor selectivity and sensitivity. ${ }^{28,33,45-47}$ Hence in our study the OANI-TMV was doped with $0.1 \mathrm{M}$ p-toluene sulfonic acid prior to evaporation. A general procedure was followed for
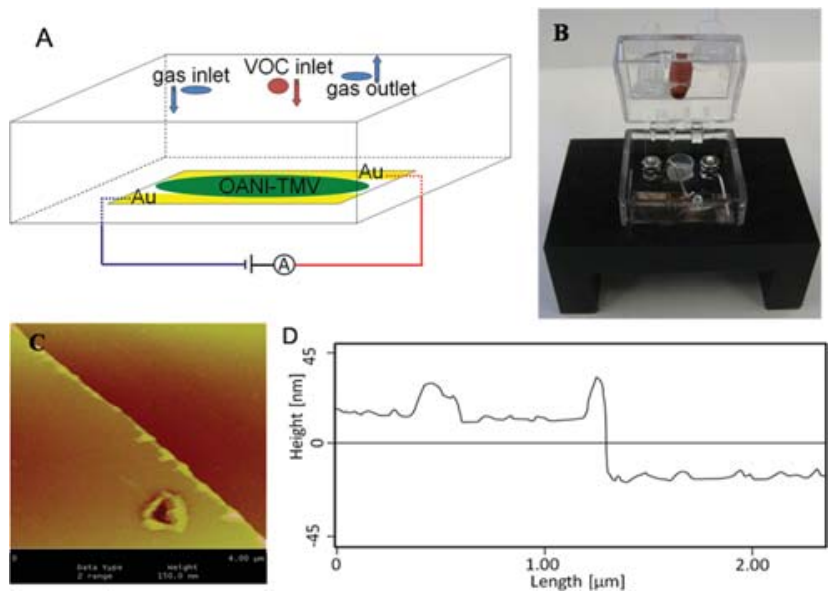

Fig. 3 (A) Schematic illustration and (B) image of the sample container used for gas sensing. (C) AFM image confirming that the height of the gold sputtered film is about $40 \mathrm{~nm}$. (D) Height profile across the edge of the film. 
sensing experiments; $50 \mu \mathrm{L}$ of organic solution was injected into the sample holder located in the middle of the sample container. The container was then sealed with parafilm and flushed with nitrogen for one minute to establish a baseline. This was also performed to remove any other contaminants from the atmosphere, such as humidity. The sealed container was then allowed to incubate for $15 \mathrm{~min}$ while the atmosphere was filled with the analyte of interest. The concentrations of the analytes were determined by their respective partial pressure at room temperature. Following the incubation time, nitrogen gas was used to flush the container of analyte and the gas desorption was seen as a sharp decrease in the current.

The plots shown in Fig. 4 display the y-values as a Response Current (RC). The RC is the ratio between the measured current $\left(\mathrm{I}_{\mathrm{X}}\right)$ and the maximum current obtained in the presence of only nitrogen $\left(\mathrm{I}_{\mathrm{N}}\right)$. This type of correction is required because there is variability in the film that leads to variability in sensitivity, but not selectivity. Films that cover the majority of the $25 \mathrm{~mm} \times$ $1.5 \mathrm{~mm}$ active area (gap between the gold sputtered films) yield
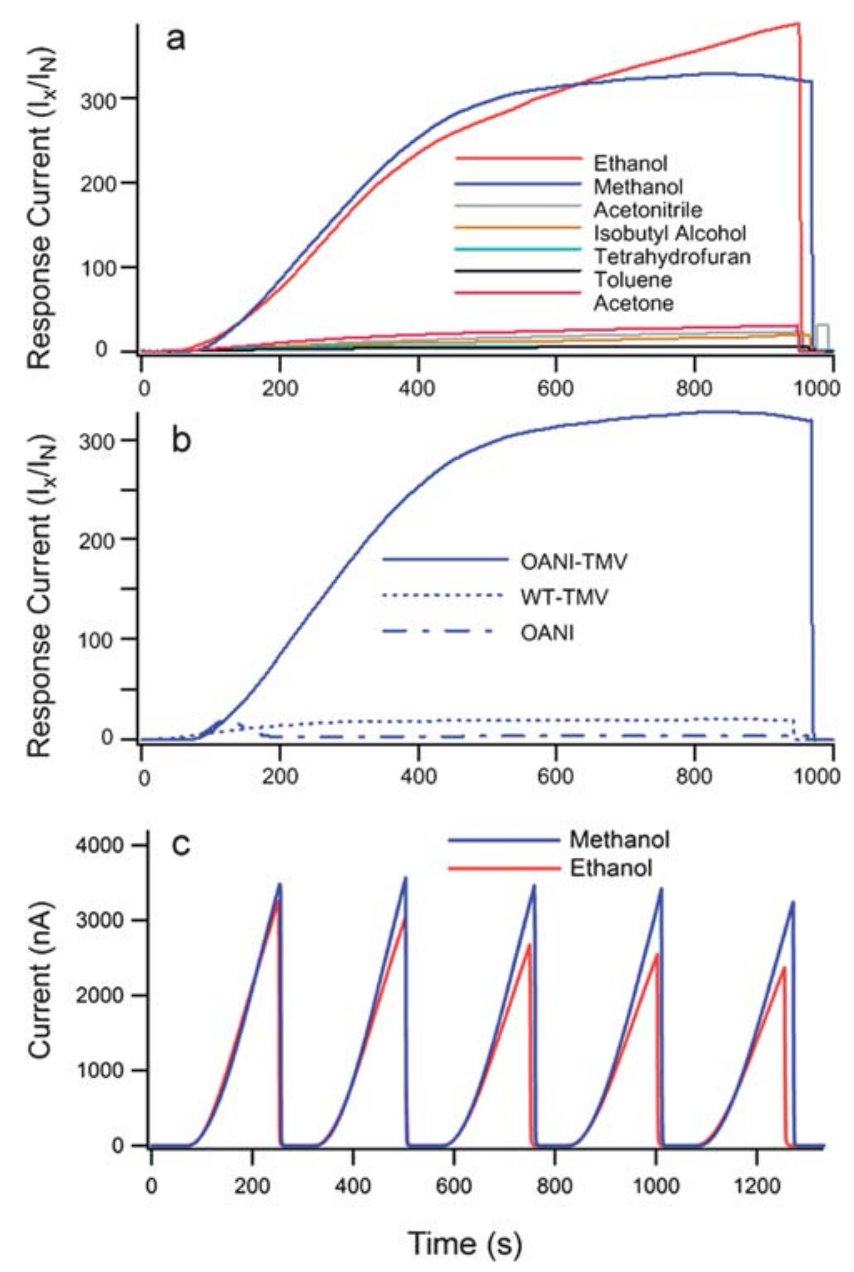

Fig. 4 (a) The selectivity of OANI-TMV thin film sensors to ethanol and methanol over acetonitrile, isobutyl alcohol, tetrahydrofuran, toluene, and acetone. (b) The response of OANI-TMV, Wt-TMV, and OANI films to methanol. (c) The repeatability of this film is shown with both ethanol (red) and methanol (blue). The applied bias during measurements was $5 \mathrm{~V}$. a higher current reading for the same film that may only cover part of the active area.

The following analytes were tested and their RC was plotted as a function of time in Fig. 4a: ethanol, methanol, isobutyl alcohol, acetonitrile, acetone, tetrahydrofuran and toluene. During this period the current of the viral film was affected differently for each analyte. The OANI-TMV shows great selectivity towards ethanol and methanol over the other analytes. Control experiments were performed by using wt-TMV and OANI alkyne thin films. WT-TMV and OANI thin films were prepared by direct deposition of TMV solution and OANI solution onto glass substrates. As shown in Fig. 4b, the RC for WT-TMV and OANI alkyne were significantly lower than OANI-TMV. This indicates that the spatial attribution of OANI ligand on the TMV surface is very critical to the response towards methanol. Two other distinct properties of this particular sensor are the quick response ability for the ethanol/methanol absorption and desorption and multi-time reproducibility (Fig. 4c).

A possible mechanism for the electrical response of OANITMV over unmodified TMV is the flexoelectric properties of TMV. ${ }^{48}$ It has been shown that when strain is placed on the rodlike particle, a small electrical response can be detected. This implies that if there is a long connected series of viral particles, combined with an outside pressure, then electrons should be able to flow through the viral film. The OANI units cause the viral particle to aggregate and form an interconnected film. The physical absorption of methanol/ethanol causes the film to swell and exerts the necessary external force to cause the desired response. Finally, the electroactive OANI assists in electron transfer through the film.

\section{Conclusions}

Using a three step bioconjugation of TMV with an electron rich OANI linker, we have shown that this scaffold provides an excellent VOC sensor. The sensor that has been developed demonstrate high selectivity towards methanol and ethanol over other VOCs. This particular property will be very useful for developing a sensor array for the analysis of real air samples with a multitude of VOCs present. Because of the versatility of the viral scaffold, it is likely that various other ligands with differing chemical properties can be attached to develop sensors with different selectivities.

\section{Acknowledgements}

This work was supported by the US NSF CAREER program, US NSF DMR, the Alfred P. Sloan Scholarship, the Camille Dreyfus Teacher Scholar Award, DoD-ARO, and the W. M. Keck Foundation.

\section{Notes and references}

1 G. T. Hermanson, Bioconjugation Tech., Academic Press, 2008.

2 H. Yi, S. Nisar, S. Y. Lee, M. A. Powers, W. E. Bentley, G. F. Payne, R. Ghodssi, G. W. Rubloff, M. T. Harris and J. N. Culver, Nano Lett., 2005, 5, 1931-1936.

3 E. Royston, A. Ghosh, P. Kofinas, M. T. Harris and J. N. Culver, Langmuir, 2008, 24, 906-912.

4 Q. Wang, T. Lin, J. E. Johnson and M. G. Finn, Chem. Biol., 2002, 9, 813-819. 
5 W. O. Dawson, D. L. Beck, D. A. Knorr and G. L. Grantham, Proc. Natl. Acad. Sci. U. S. A., 1986, 83, 1832-1836.

6 W. Shenton, T. Douglas, M. Young, G. Stubbs and S. Mann, $A d v$. Mater., 1999, 11, 253-256.

7 E. Dujardin, C. Peet, G. Grubbs, J. N. Culver and S. Mann, Nano Lett., 2003, 3, 413-417.

8 C. Mao, D. J. Solis, B. D. Reiss, S. T. Kottmann, R. Y. Sweeney, A. Hayhurst, G. Georgiou, B. Iverson and A. M. Belcher, Science, 2004, 303, 213-217.

9 T. Douglas and M. Young, Nature, 1998, 393, 152-155.

10 T. Douglas and M. Young, Adv. Mater., 1999, 11, 679-681.

11 D. Willits, X. Zhao, N. Olson, T. S. Baker, A. Zlotnick, J. E. Johnson, T. Douglas and M. J. Young, Virology, 2003, 306, 280-288.

12 Z. Varpness, J. W. Peters, M. Young and T. Douglas, Nano Lett., 2005, 5, 2306-2309.

13 M. Allen, J. W. Bulte, L. Liepold, G. Basu, H. A. Zywicke, J. A. Frank, M. Young and T. Douglas, Magn. Reson. Med., 2005, 54, 807-812.

14 M. Uchida, M. L. Flenniken, M. Allen, D. A. Willits, B. E. Crowley, S. Brumfield, A. F. Willis, L. Jackiw, M. Jutila, M. J. Young and T. Douglas, J. Am. Chem. Soc., 2006, 128, 16626-16633.

15 L. Liepold, S. Anderson, D. Willits, L. Oltrogge, J. A. Frank, T. Douglas and M. Young, Magn. Reson. Med., 2007, 58, 871-879.

16 M. Young, D. Willits, M. Uchida and T. Douglas, Annu. Rev. Phytopathol., 2008, 46, 361-384.

17 Z. Liu, C. Davis, W. Cai, L. He, X. Chen and H. Dai, Proc. Natl. Acad. Sci. U. S. A., 2008, 105, 1410-1415.

18 M. E. Akerman, W. C. Chan, P. Laakkonen, S. N. Bhatia and E. Ruoslahti, Proc. Natl. Acad. Sci. U. S. A., 2002, 99, 12617-12621.

19 J. Lim and E. E. Simanek, Org. Lett., 2008, 10, 201-204.

20 A. Klug, Philos. Trans. R. Soc. London, Ser. B, 1999, 354, 531-535.

21 D. Harrison and T. M. Wilson, Philos. Trans. R. Soc. London, Ser. B, 1999, 354, 521-529.

22 A. Klug, Harvey Lectures, 1980, 74, 141-172.

23 R. A. Miller, A. D. Presley and M. B. Francis, J. Am. Chem. Soc., 2007, 129, 3104-3109.

24 Z. Niu, M. Bruckman, V. S. Kotakadi, J. He, T. Emrick, T. P. Russell, L. Yang and Q. Wang, Chem. Commun., 2006, 3019-3021.

25 Z. Niu, J. Liu, L. A. Lee, M. A. Bruckman, D. Zhao, G. Koley and Q. Wang, Nano Lett., 2007, 7, 3729-3733.

26 Z. Niu, M. A. Bruckman, S. Li, L. A. Lee, B. Lee, S. V. Pingali, P. Thiyagarajan and Q. Wang, Langmuir, 2007, 23, 6719-6724.
27 M. A. Bruckman, G. Kaur, L. A. Lee, F. Xie, J. Sepulveda, R. Breitenkamp, X. Zhang, M. Joralemon, T. P. Russell, T. Emrick and Q. Wang, ChemBioChem, 2008, 9, 519-523.

28 H. Bai and G. Shi, Sensors, 2007, 7, 267-307.

29 J. Rong, F. Oberbeck, X. Wang, J. Oxsher, Z. Niu and Q. Wang, J. Mater. Chem., 2009, 21, 2841-2845.

30 Rajesh, T. Ahuja and D. Kumar, Sens. Actuators, B, 2009, 136, 275 286.

31 G. MacDiarmid, Angew. Chem., Int. Ed., 2001, 40, 2581-2590.

32 J. Huang, S. Virji, B. H. Weiller and R. B. Kaner, Chem.-Eur. J., 2004, 10, 1314-1319.

33 S. Virji, J. X. Huang, R. B. Kaner and B. H. Weiller, Nano Lett., 2004, 4, 491-496.

34 X. Yu, Y. Li and K. Kalantar-zadeh, Sens. Actuators, B, 2009, 136, $1-7$.

35 J. Huang, S. Virji, B. H. Weiller and R. B. Kaner, J. Am. Chem. Soc., 2003, 125, 314-315.

36 Z.-F. Li, F. D. Blum, M. F. Bertino, C.-S. Kim and S. K. Pillalamarri, Sens. Actuators, B, 2008, 134, 31-35.

37 R. Chen and B. C. Benicewicz, Synth. Met., 2004, 146, 133-137.

38 Y. Guo, M. Li, A. Mylonakis, J. Han, A. G. MacDiarmid, X. Chen, P. I. Lelkes and Y. Wei, Biomacromolecules, 2007, 8, 3025-3034.

39 M. Riskin, R. Tel-Vered, T. Bourenko, E. Granot and I. Willner, J. Am. Chem. Soc., 2008, 130, 9726-9733.

40 M. M. Ayad and N. L. Torad, Talanta, 2009, 78, 1280-1285.

41 M. M. Ayad, G. El-Hefnawey and N. L. Torad, J. Hazard. Mater., $2009, \mathbf{1 6 8}, 85-88$.

42 C. Mao, A. Liu and B. Cao, Angew. Chem., Int. Ed., 2009, 48, 67906810.

43 R. Turner, C. J. McGuigan and P. J. Butler, J. Mol.Biol., 1989, 209, 407-422.

44 T. L. Schlick, Z. Ding, E. W. Kovacs and M. B. Francis, J. Am. Chem. Soc., 2005, 127, 3718-3723.

45 S. Virji, B. H. Weiller, J. X. Huang, R. Blair, H. Shepherd, T. Faltens, P. C. Haussmann, R. B. Kaner and S. H. Tolbert, J. Chem. Educ., 2008, 85, 1102-1104.

46 D. Verma and V. Dutta, Sens. Actuators, B, 2008, 134, 373-376.

47 H. D. Tran, K. Shin, W. G. Hong, J. M. D’Arcy, R. W. Kojima, B. H. Weiller and R. B. Kaner, Macromol. Rapid Commun., 2007, 28, 2289-2293.

48 S. V. Kalinin, S. Jesse, W. L. Liu and A. A. Balandin, Appl. Phys. Lett., 2006, 88, 153902. 